\title{
A META-ANALYSIS OF PIPERACILLIN/TAZOBACTAM VERSUS CEFEPIME TREATMENT IN CANCER PATIENTS WITH FEBRILE NEUTROPENIA
}

\author{
UMA META ANÁLISE DE PIPERACILINA/TAZOBACTAM VERSUS TRATAMENTO \\ COM CEFEPIMA EM PACIENTES ONCOLÓGICOS COM NEUTROPENIA FEBRIL
}

\section{Zhang WEIDONG ${ }^{1 *}$; Xiao CHUN ${ }^{2 *}$; Zhou SIXIN ${ }^{3}$; Wang RUI ${ }^{1}$; Wang LI $^{1}$; Jia LIPING ${ }^{1}$; Ma JINQIU ${ }^{1}$; Wang NA ${ }^{1}$}

1. The First Hospital of Qinhuangdao, Qinhuangdao 066000 China; 2. Department of General Surgery, The General Hospital of The PLA Rocket Force; 3. Department of General Surgery, Chinese People's Liberation Army General Hospital, Beijing 100853 China. *These authors contributed to the work equllly and should be regarded as co-first authors. ${ }^{+}$Corresponding author: Wang Na. The First Hospital of Qinhuangdao, Qinhuangdao, China. Email: wangnamd@ gmail.com

\begin{abstract}
Febrile neutropenia (FN) causes a major threat to cancer patients after chemotherapy. Broadspectrum antibiotic treatment is a well-established practice for febrile neutropenia. Piperacillin/Tazobactam (P/T) is the frequently used antibiotic in most of FN cases, whereas the use of cefepime remains unclear regarding its potential risk. However, little systematic analysis has been conducted about comparison between these two drugs. Thus, we undertook this meta-analysis to compare these two monotherapies for febrile neutropenia. Through searching Pubmed, Google scholar, Medline databases, EMBASE, OvidSP, ScienceDirect, Web of science, and China Journal Net (CJN) databases, we used the keywords "(Piperacillin/Tazobactam AND cefepime) AND (febrile neutropenia) AND (cancer or tumor)". Only studies with randomized controlled trials were included in the meta-analysis. We screened out a total number of seven clinical trials. This meta-analysis supported that $\mathrm{P} / \mathrm{T}$ treatment was superior to cefepime treatment based on the average OR comparison, without statistical significance $(\mathrm{OR}=1.27,95 \%$ confidence interval $=0.98$ to $1.64, \mathrm{p}=0.07)$. We further divided the seven studies into two subgroups based on age and treatment time. The young group (age <=19) showed no significant difference $(\mathrm{OR}=1.10, \mathrm{p}=0.65)$. While the old group (age $>19)$ showed that $\mathrm{P} / \mathrm{T}$ treatment was better than cefepime with statistical difference $(\mathrm{OR}=1.44, \mathrm{p}=0.05)$. The short-term group (time $<=3 \mathrm{ds})$ showed $\mathrm{P} / \mathrm{T}$ treatment was better than cefepime with statistical difference $(\mathrm{OR}=1.40, \mathrm{p}=0.05)$. While in the long-term group (time $>$ $5 \mathrm{ds})$, there was no significant difference between $\mathrm{P} / \mathrm{T}$ and cefepime therapy $(\mathrm{OR}=1.06, \mathrm{p}=0.79)$ Asymmetry in Funnel plots indicated no publication bias $\left(\mathrm{CHI}^{2}=1.47, \mathrm{I}^{2}=0 \%\right.$, and p-value $\left.=0.96\right)$ in this meta-analysis. It would be a good clinical trial to use P/T treatment to cure FN in cancer patients compared with cefepime treatment, especially in adult patients or patients with a short-term treatment period. This meta-analysis is practically important during antibiotic treatment in FN management.
\end{abstract}

KEYWORDS: Meta-analysis. Piperacillin/Tazobactam. Cefepime. Febrile neutropenia. Cancer.

\section{INTRODUCTION}

Cancer is still the major threat to human health and life. Chemotherapy and radiotherapy are two frequently used strategies to treat most common cancers.(JAMES et al., 2012) Despite of the recent improvement of medical management and infection prevention, chemotherapy-induced neutropenic complications, such as febrile neutropenia (FN) and mortality, remain a major cause of morbidity and death of cancer patients.(KUDERER et al., 2006) Chemotherapy-induced FN is a fever symptom in patients with signs of infection and abnormally low number of neutrophil granulocytes. FN is often accompanied with considerable morbidity, treatment failure, and costs during cancer therapy.(LYMAN et al., 2014) It is reported that more than half of the cancer patients have FN symptom at some particular period during cancer treatment.(FREIFELD et al., 2011) Several studies and treatment approaches have been performed for decades and clinicians have formed the standard treatment using empirical intravenous antibiotics for $\mathrm{FN}$ in cancer patients.(LYMAN et al., 2014; TEUFFEL et al., 2011; VIDAL et al., 2013) Thus, it is quite important to find out one of the most effective antibiotics in the treatment of FN.

Generally, the prompt administration of a wide-spectrum antipseudomonal $\beta$-lactam agent together with an aminoglycoside is recommended in the guidelines.(DEL FAVERO et al., 2001) Up to now, there has been no consensus on the optimal antibiotic for FN therapy. P/T (the $\beta$-lactam- $\beta$ lactamase inhibitor combinations) is most commonly used antibiotic in FN cases and is usually consistently available as Tazocin in the hospital pharmacy in most countries, such as China, Turkey and the USA. (FANGLI et al., 2011; SERAP et al., 2012; SIPAHI et al., 2014; TAMME et al., 2016) Cefepime (Broad-spectrum antipseudomonal cephalosporins) monotherapy has also been shown to be effective in some cancer patients with febrile 
granuloc ytopenia. (B HME et al., 1998; MONTALAR et al., 2002) However, a controversy raised about whether cefepime caused a higher risk in patients compared with other antibiotics. One included study in this article stated that $\mathrm{P} / \mathrm{T}$ treatment was more effective than cefepime treatment.(BOW et al., 2006) On the other hand, a meta-analysis conducted by the US Food and Drug Administration (FDA) demonstrated there was no significant difference between cefepime and other antibiotics treatment such as P/T. (WINGARD et al., 2013) Those studies only compared the differences between cefepime and a broad range of other $\beta$-lactam antibiotics but may omit some critical information about comparing the efficacy between cefepime treatment and some other specific antibiotic treatments. Because $\mathrm{P} / \mathrm{T}$ is one of the most widely applied antibiotics to treat infection in hospitals and cancer centers, we conducted a detailed analysis to compare $\mathrm{P} / \mathrm{T}$ with cefepime monotherapy in $\mathrm{FN}$ episode in cancer patients.

Piperacillin/tazobactam (PIP/TAZO) is a well-known antagonist of $\beta$-lactamase, which is a bacterial enzyme disabling the function of antibiotics. Piperacillin belongs to the extendedspectrum penicillin against most gram-positive and gram-negative organisms.(BRISMAR et al., 1992) Tazobactam is a newly developed P-lactamase inhibitor of the penicillanic acid sulfone class with a similar structure to sulbactam but more active than sulbactam against enterobacteria. Piperacillin/tazobactam in combination is effective in infection treatments in both children and adults. Cefepime is another fourth-generation cephalosporin antibiotic with a broader spectrum of activity against Gram-positive and Gram-negative bacteria.(JANDULA et al., 2001) It is widely applied in clinical trials against infection worldwide due to its superior pharmacological characteristics. Several reports have indicated the effectiveness of cefepime, both with monotherapy or combination therapy, on FN treatment.(MONTALAR et al., 2002) However, a disputed point stated that patient mortality will increase when treated with cefepime but not the other $\beta$-lactam antibiotics.(LEIBOVICI et al., 2010) There are still some concerns about the cefepime treatment efficacy and risk. Few relevant evidence or systematic analyses have been reported about the difference between $\mathrm{P} / \mathrm{T}$ and cefepime treatment in FN. In an attempt to get a better understanding of the difference between $\mathrm{P} / \mathrm{T}$ and cefepime efficacy, we therefore searched for all randomized controlled studies about these two drugs and conducted a systematical review to compare these antibiotic empirical monotherapies.

\section{MATERIAL AND METHODS}

\section{Literature search strategy}

We applied the following databases for literature search, including Pubmed, Google scholar, Medline databases, EMBASE, OvidSP, ScienceDirect, Web of science, and China Journal Net (CJN) databases. We included studies and reports regardless of publishing date, language, or publication. In the selection criteria, we only included randomized clinical trials which compared the $\mathrm{P} / \mathrm{T}$ with cefepime monotherapy in cancer patients with FN episodes. FN was defined as a fever symptom in patients with signs of infection and an abnormally low number of neutrophil granulocytes. For the first screen of the studies, we used a relative loose search strategy with the key words (Piperacillin/tazobactam OR cefepime) AND (febrile neutropenia) AND (cancer or Tumor), aiming at getting as many relevant records as possible. Then we narrowed down the scope of the publications with regards to the clinical trials in cancer patients treated with P/T and cefepime. We only evaluated and studied the primary outcome, which was defined by fever symptom, duration of fever, and neutropenia. Finally, five papers published in English, one English conference abstract and one paper published in Chinese were included and analyzed in this meta-analysis.

\section{Selection standard}

Studies were chosen for meta-analysis if the experimental design was randomized with controlled clinical studies. Studies including P/T or cefepime combination therapy are excluded. Case reports, review articles, bacteria susceptibility surveillance, and other non-clinical studies were excluded.

\section{Outcome measures}

The primary outcome is determined by the recovery from fever with disappearance of signs of infection and fever without modifications of initial empirical treatment.

\section{Data extraction}

We used the uniform form which extracted information from all included studies, including published information such as author, year, study type, type of infection, drug administration doses, participant size, age, sex proportion, and type of cancer. 


\section{Statistics}

All the test process was done by Review Manager 5.3. Through the collection of binary outcomes of patients treated with $\mathrm{P} / \mathrm{T}$ and cefepime monotherapy from the seven clinical trials, odds ratios (OR) and 95\% confidence intervals (CIs) were then calculated using the random-effects model of DerSimonian and Laird. The publication bias was assessed by the $\mathrm{I}^{2}$ measure based on the Breslow-Day test. If $\mathrm{I}^{2}$ was below $25 \%$, the studies were considered to be homogeneous. If $\mathrm{I}^{2}$ was $>50 \%$ or $>75 \%$, the studies were considered to be heterogeneous. If $\mathrm{I}^{2}$ statistic $(>50 \%)$ and a 2 -sided $\mathrm{p}$ value $<0.05$ was considered to indicate statistical significance.

\section{RESULTS}

\section{Literature search}

Through searching the journal database (Pubmed, Google scholar, Medline databases,
WEIDONG, Z. et al.

EMBASE, OvidSP, ScienceDirect, Web of science, and China Journal Net (CJN) databases) for the studies related to $\mathrm{P} / \mathrm{T}$ and cefepime clinical trial, we got a total number of 243 journals (Fig. 1), indicating that relative few clinical trials have been conducted about the differences between $\mathrm{P} / \mathrm{T}$ and cefepime therapy. Of these studies, 232 articles were subsequently excluded because they did not meet the eligibility criteria based on examination of their subjects, such as reviews or case reports. 11 articles which focus on the study of $\mathrm{P} / \mathrm{T}$ and cefepime treatment in cancer patients with FN symptom were further screened out. After a careful review of these 11 articles, another 4 articles were not included because they were neither monotherapy (such as Sanz 2002)(SANZ et al., 2002) nor clinical study (such as Jacobson 1999).(JACOBSON et al., 1999) Finally, a total number of seven studies were included in the meta-analysis.

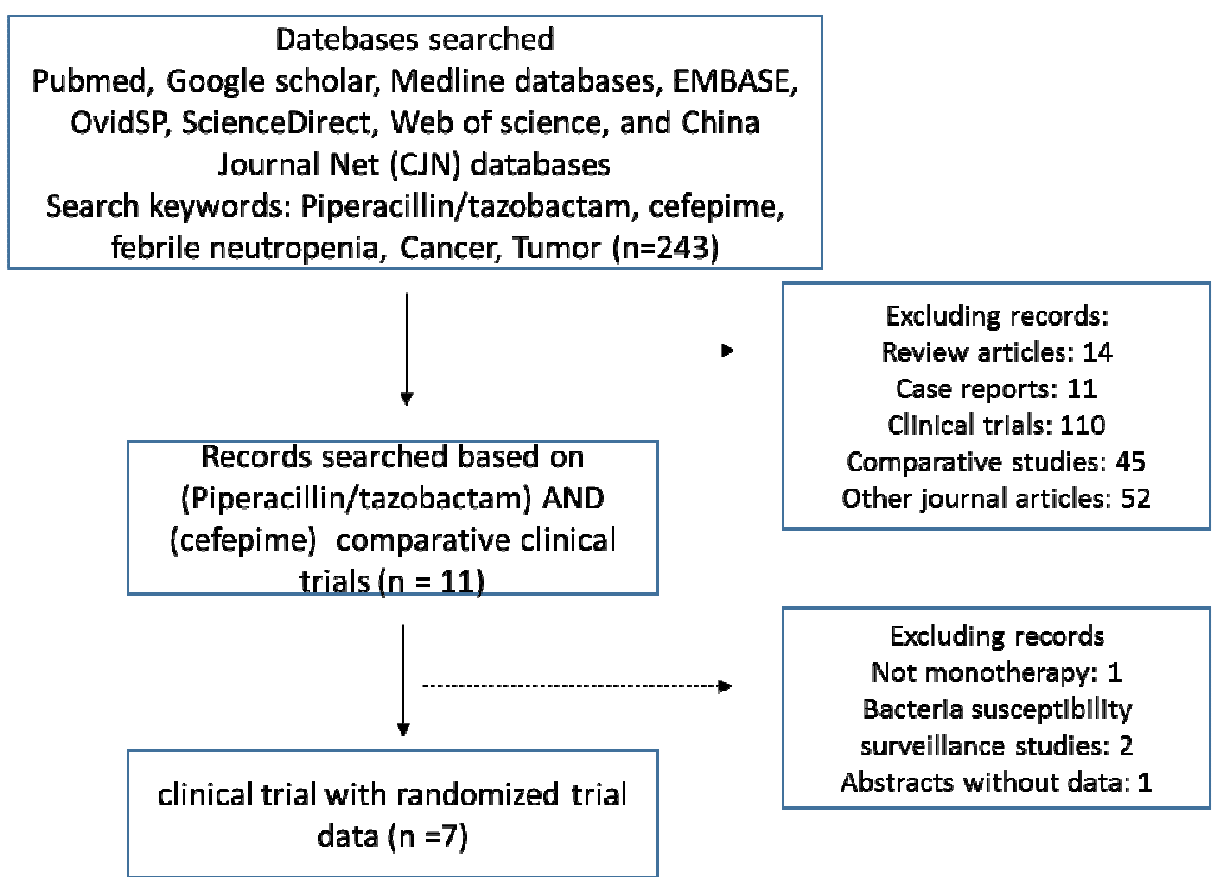

Figure 1. scheme of screening out studies related to $\mathrm{P} / \mathrm{T}$ vs cefepime in cancer patients with FN cases.

\section{Study characteristics}

The selected seven studies are listed in Table 1 with summarized features.(B HME et al., 1998; BOW et al., 2006; CORAPCIOGLU et al., 2006; FANGLI et al., 2011; SANO et al., 2015; UYGUN et al., 2009; WI et al., 2008) All of these articles were prospective studies. The total number of participants treated with $\mathrm{P} / \mathrm{T}$ was 591 and the number of patients treated with cefepime was 577 . The patients from three articles (FUNDA, 2015; VEDAT, 2009; HIROZUMI, 2015) were $<=19$ years old. Other patients from three studies (BOW, 2006, HUA 2010; WI, 2008) were $>19$ years old (the age of adult patients in Wi 2008 study was treated to be larger than 19). The treatment time from four studies (BOW, 2006; BHME, 1998; FUNDA, 2015; WI, 2008) was shorter than 3 days. The treatment time from other two studies (HIROZUMI, 2015; VEDAT 2009) was longer than 5 days. The type of pathogens included Grampositive, Gram-negative organisms and other pathogens. Four studies provide the details of P/T 
and cefepime administration dosage except three studies (Table 1). All the studies have used antibiotic monotherapy without any combination treatment. Furthermore, all the patients in these
WEIDONG, Z. et al.

seven studies received randomized clinical trials. Finally, the types of cancer in all patients in the meta-analysis are majorly Leukemia, Myeloma, lymphoma or solid tumor.

Table 1. Characteristics of studies included in the meta-analysis.

\begin{tabular}{|c|c|c|c|c|c|c|c|}
\hline Author, year, reference & Study type & $\begin{array}{l}\text { Type of } \\
\text { Infection }\end{array}$ & Drug doses & $\begin{array}{l}\text { partlclpa } \\
\text { nts }\end{array}$ & Age & $\%$ Male & Type of cancer \\
\hline ᄃ. I. Bow et al. (7006) & $\begin{array}{l}\text { Randomized } \\
\text { study }\end{array}$ & $\begin{array}{l}\text { Gram } \\
\text { negative and } \\
\text { positive } \\
\text { organisms }\end{array}$ & $\begin{array}{l}\mathrm{P} / \mathrm{T}(4.5 \mathrm{~g} \text { every } 6 \mathrm{~h} \text { ) or cefepime } \\
\text { (2g every } 8 \mathrm{~h} \text { ) for } 3 \text { days }\end{array}$ & $\begin{array}{l}265 \text { for } \\
P / T \text { and } \\
263 \text { for } \\
\text { cetepime }\end{array}$ & $\begin{array}{l}52(1783) \text { for } \\
\mathrm{P} / \mathrm{T} \text { and } 52(18 \\
79) \text { for } \\
\text { cetepime }\end{array}$ & $\begin{array}{l}166(62.6) \text { for } \\
\mathrm{P} / \mathrm{T} \text { and } 146 \\
(55.5) \text { for } \\
\text { cetepime }\end{array}$ & $\begin{array}{l}\text { leukemia and } \\
\text { lymphoma }\end{array}$ \\
\hline $\begin{array}{l}\text { Funda Corapcioglu et al. } \\
\text { (2006) }\end{array}$ & $\begin{array}{l}\text { prospective } \\
\text { and } \\
\text { randomized } \\
\text { study }\end{array}$ & $\begin{array}{l}\text { Gram- } \\
\text { negative and } \\
\text { positive } \\
\text { organisms }\end{array}$ & $\begin{array}{l}80 \mathrm{mg} / \mathrm{kg} \text { Piperacilin } 10 \mathrm{mg} / \mathrm{kg} \\
\text { tarohactam every } 6 \mathrm{~h} \text { (maximum } \\
4.6 \mathrm{~g} / \text { dosc) cefcpimc } 50 \mathrm{mg} / \mathrm{kg} \\
\text { cvery } 8 \mathrm{~h} \text { (maximum } 2 \mathrm{~g} / \mathrm{dosc} \text { ) } \\
\text { for } 4 \text { days }\end{array}$ & $\begin{array}{l}25 \text { for } P / T \\
\text { and } 25 \\
\text { for } \\
\text { cefepime }\end{array}$ & $\Leftrightarrow=18$ & NA & $\begin{array}{l}\text { leukemia and } \\
\text { solid tumor }\end{array}$ \\
\hline $\begin{array}{l}\text { Hirozumi Sano et al. } \\
\text { (2015) }\end{array}$ & $\begin{array}{l}\text { compar alive } \\
\text { and } \\
\text { randomized } \\
\text { study }\end{array}$ & NA & 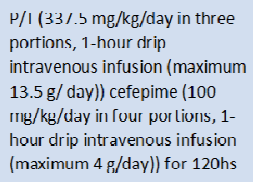 & $\begin{array}{l}103 \text { fur } \\
P / T \text { and } \\
110 \text { for } \\
\text { cetepime }\end{array}$ & $\begin{array}{l}4(0-70) \text { for } \Gamma / T \\
\text { and } \sigma(0-3>) \text { for } \\
\text { cefepime }\end{array}$ & $\begin{array}{l}103(16.6) \text { for } P / T \\
\text { and } 110(48.2)\end{array}$ & $\begin{array}{l}\text { Tleukemia and } \\
\text { solid tumor }\end{array}$ \\
\hline Hua Fangli et al. (2010) & $\begin{array}{l}\text { Randomized } \\
\text { study }\end{array}$ & $\begin{array}{l}\text { Graml- } \\
\text { negative and } \\
\text { positive } \\
\text { organisms }\end{array}$ & NA & $\begin{array}{l}31 \mathrm{for} P / T \\
\text { and } 27 \\
\text { for } \\
\text { cefepime }\end{array}$ & 64 (49 84) & $37(58.7)$ & Myeloma \\
\hline Vedat Uygun et al. (2009) & $\begin{array}{l}\text { prospective } \\
\text { and } \\
\text { randomized } \\
\text { study }\end{array}$ & $\begin{array}{l}\text { Gram- } \\
\text { negative and } \\
\text { positive } \\
\text { organisms }\end{array}$ & $\begin{array}{l}80 \mathrm{mg} / \mathrm{kg} \text { piperacillin } 10 \mathrm{mg} / \mathrm{kg} \\
\text { tarohactam every } 6 \mathrm{~h} \text { or } \\
\text { cefepime } 50 \mathrm{mg} / \mathrm{kg} \text { every } 8 \mathrm{~h} \text { for } \\
5 \text { days }\end{array}$ & $\begin{array}{l}\text { bs for } P / 1 \\
\text { and } 6> \\
\text { for } \\
\text { cefepime }\end{array}$ & $\begin{array}{l}3.8(0.3-19) \text { for } \\
P / T \text { and } 4.0 \\
(0.3-19) \text { for } \\
\text { cefepime }\end{array}$ & $\begin{array}{l}31(52.3) \text { for } P / T \\
\text { and } 30(48.4) \text { tor } \\
\text { cetepime }\end{array}$ & $\begin{array}{l}\text { leukemia and } \\
\text { lymphnma }\end{array}$ \\
\hline Y.M. Wi et al. (2008) & $\begin{array}{l}\text { prospective } \\
\text { and } \\
\text { randomized } \\
\text { sludy }\end{array}$ & $\begin{array}{l}\text { microbiology } \\
\text { organisms }\end{array}$ & NA & $\begin{array}{l}48 \text { for } \mu / 1 \\
\text { and } 41 \\
\text { for } \\
\text { cerepirite }\end{array}$ & $\begin{array}{l}\text { adult cancer } \\
\text { paticnts }\end{array}$ & NA & NA \\
\hline A Röhme et al. (1998) & $\begin{array}{l}\text { pruspective } \\
\text { and } \\
\text { randomized } \\
\text { study }\end{array}$ & $\begin{array}{l}\text { Gr unI } \\
\text { negative and } \\
\text { positive } \\
\text { organisms }\end{array}$ & NA & $\begin{array}{l}51 \text { lor } P / T \\
\text { and } / 9 \\
\text { for } \\
\text { cetepime }\end{array}$ & NA & NA & NA \\
\hline
\end{tabular}

\section{Clinical response rate}

From Figure 2, among the seven studies, we found none of them showed the significant difference between $\mathrm{P} / \mathrm{T}$ and cefepime treatment (Figure 2). The combined OR indicated that P/T monotherapy showed a higher efficacy than cefepime monotherapy with a $\mathrm{p}$-value $=0.07$. OR overall average was 1.27 ranged from 0.98 to 1.64 . For the age of patients from the chosen studies varies differently, we further divided the four studies into two subgroups based on age, the young group (age $<=19$ ) and the old group (age $>19$ ). The young group showed no significant difference between P/T and cefepime treatment (Figure 3: odds ratio $=1.10,95 \%$ confidence interval $=0.73$ to 1.65 , $p=0.65$ ). While the old group showed that $P / T$ treatment was superior to cefepime treatment with significant difference (Fig. 4: odds ratio $=1.44,95 \%$ confidence interval $=1.00$ to $2.09, \mathrm{p}=0.05)$. We also noticed that the duration time of antibiotic administration was different. The short-term group (time $<=3 \mathrm{ds}$ ) showed $\mathrm{P} / \mathrm{T}$ treatment is better than cefepime with statistical difference (Fig. 5: odds ratio $=1.40,95 \%$ confidence interval $=1.00$ to 1.95 , $\mathrm{p}=0.05$ ). While in long-term group (time $>5 \mathrm{ds}$ ), there is no significant difference between $\mathrm{P} / \mathrm{T}$ and cefepime therapy (Fig. 6: odds ratio $=1.06,95 \%$ confidence interval $=0.69$ to $1.64, \mathrm{p}=0.79$ ).

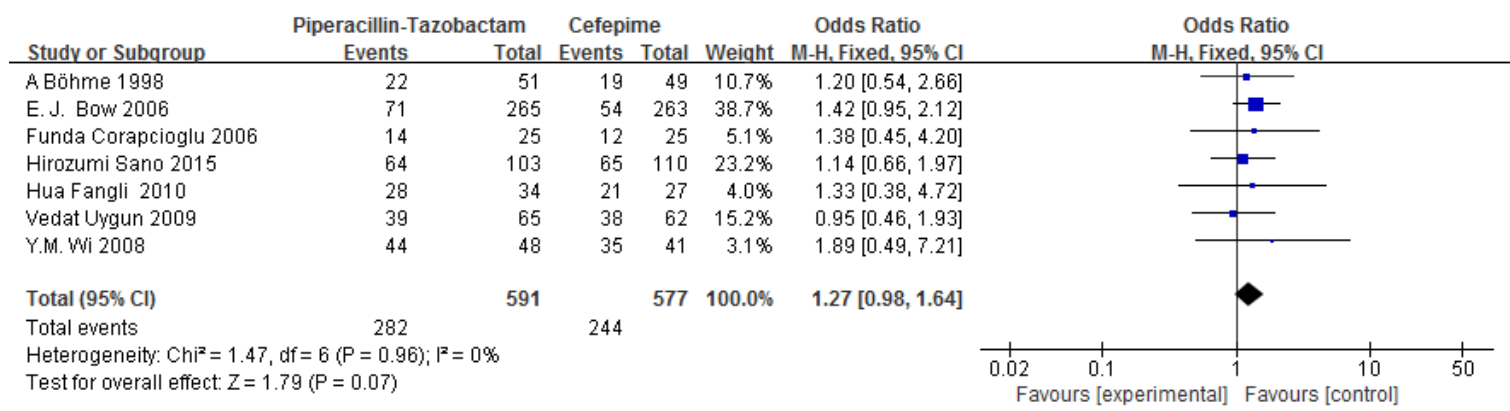

Figure 2. Clinical response rate of $\mathrm{P} / \mathrm{T}$ vs cefepime in the treatment of $\mathrm{FN}$ in cancer patients 


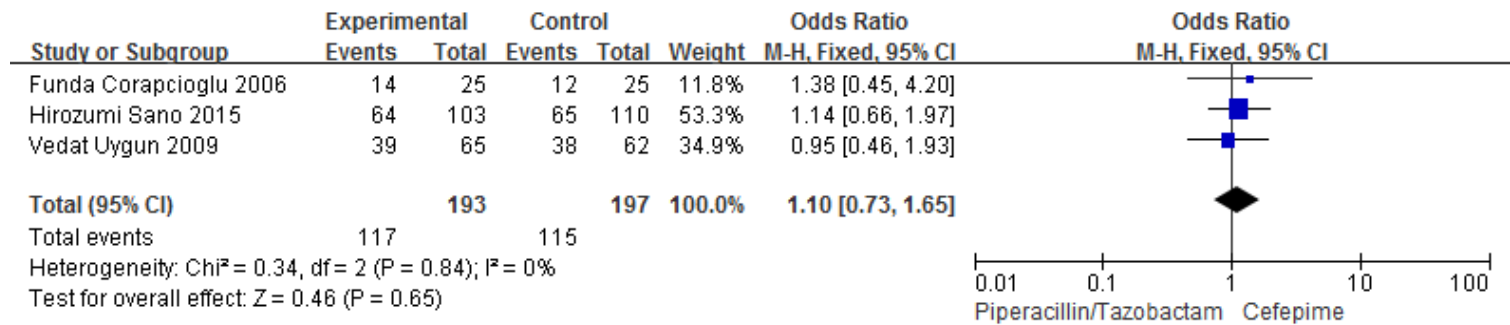

Figure 3. Clinical response rate of $\mathrm{P} / \mathrm{T}$ vs cefepime in the treatment of $\mathrm{FN}$ in the young group

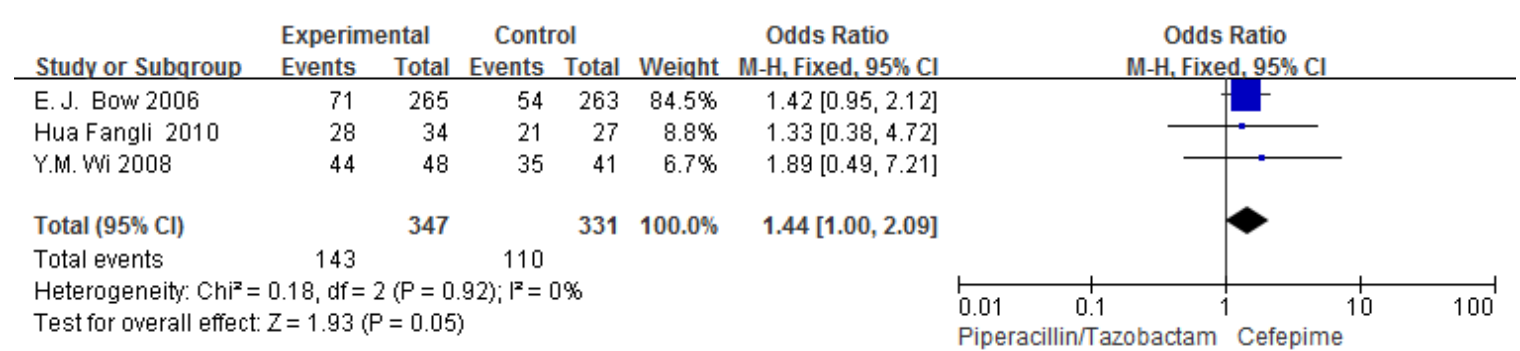

Figure 4. Clinical response rate of $\mathrm{P} / \mathrm{T}$ vs cefepime in the treatment of FN in the old group

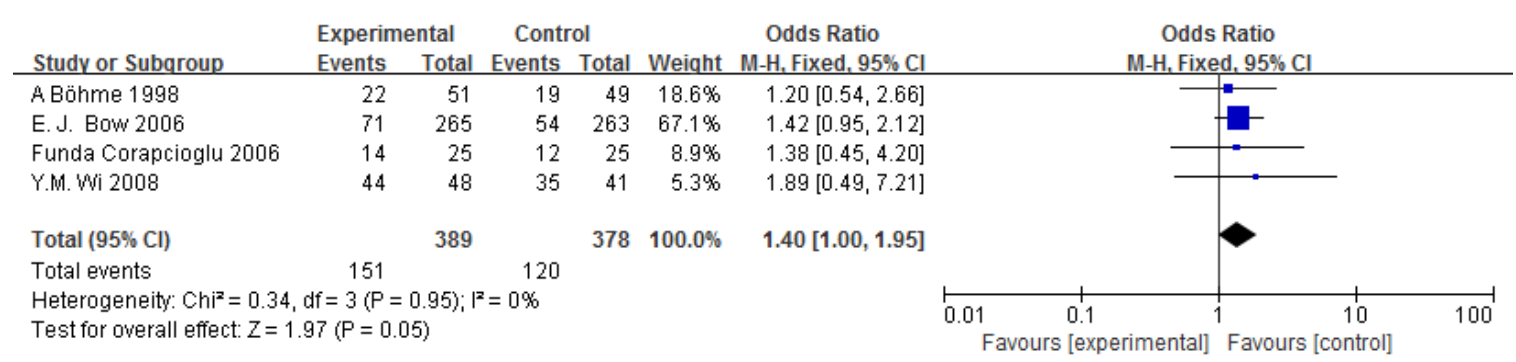

Figure 5. Clinical response rate of $\mathrm{P} / \mathrm{T}$ vs cefepime in the treatment of $\mathrm{FN}$ in the short-term group

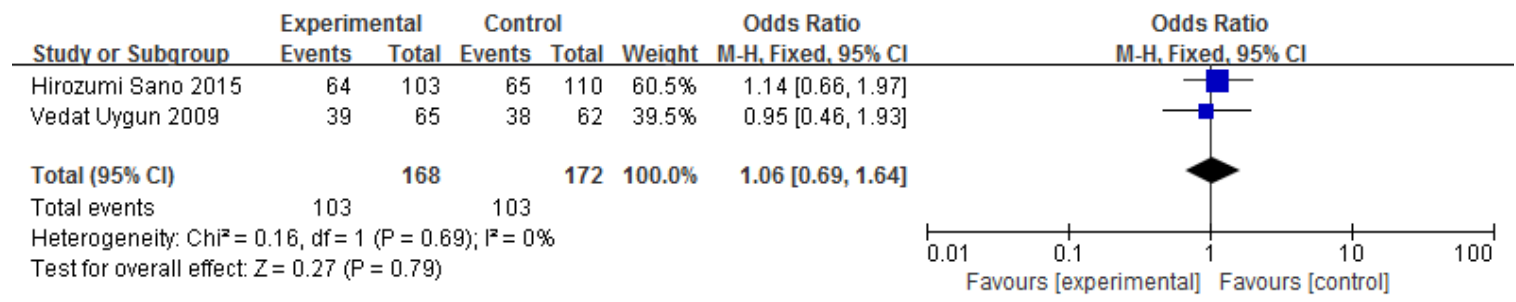

Figure 6. Clinical response rate of $\mathrm{P} / \mathrm{T}$ vs cefepime in the treatment of $\mathrm{FN}$ in the long-term group

\section{Publication bias}

All the groups included in this study were checked to be heterogeneous by a chi-square-based test in Fig. $7\left(\mathrm{CHI}^{2}=1.47, \mathrm{I}^{2}=0 \%\right.$, and p-value $=$ 0.96). So it would be a fixed-effects model for further analysis. There was no publication bias based on the Funnel plot in Figure 7 (X axis showed
OR value and $\mathrm{Y}$ axis: standard error by $\log \mathrm{OR}$ for the clinical response rate). For the clinical response rate, the combined effect size yielded a $\mathrm{Z}$-value of $=1.79$, with a corresponding $p$-value of 0.07 . As the overall clinical response rate in all studies was not significantly different from each other, the fail-safe $\mathrm{n}$ value was irrelevant. 


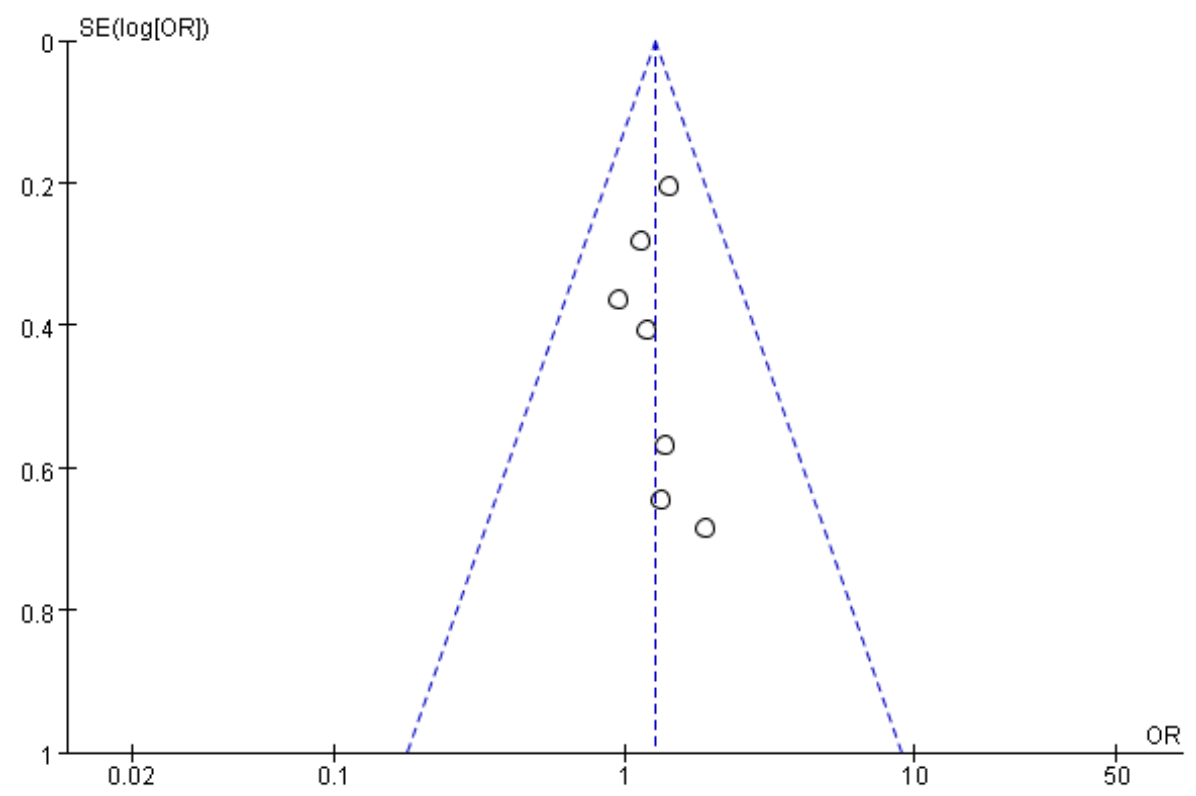

Figure 7. Funnel plot of the standard error by log odds raio for the clinical response rate and OR. The plot showed the publication bias is symmetry and no publication bias.

\section{DISCUSSION}

Up to our knowledge, there are several reviews or meta-analysis about FN management or antibiotic application during FN patient treatment, such as in Robinson's, Morgan's, and Philip's review, they have evaluated the antibiotic monotherapy for FN management and evidencebased guidelines in pediatric patients; (LEHRNBECHER et al., 2012; MORGAN et al., 2014; ROBINSON et al., 2016) in Paul's metaanalysis, they combined different empirical broadspectrum antibiotic treatments together and found an increased mortality with cefepime therapy. (PAUL et al., 2006)However, few evidence or details have been focused on the comparison between $\mathrm{P} / \mathrm{T}$ and cefepime monotherapy in cancer patients with FN. This meta-analysis is the first systematic and detailed review to compare the drug response rate between $\mathrm{P} / \mathrm{T}$ and cefepime for the treatment of FN in cancer patients. We finally screened out a total number of 1162 patients from seven studies. Both the number of the study and sample size matched the criteria requirements in this meta-analysis. Analysis of the data extracted from these studies reveals that $\mathrm{P} / \mathrm{T}$ monotherapy is superior to cefepime drug treatment, with a p-value $=0.07$. This result is consistent with Paul's study which has indicated that cefepime treatment is accompanied with increased mortality. (PAUL et al., 2006) If more clinical trials could be conducted and included into the meta-analysis, we could make our findings more conclusive.
Based on Figure 1, there was not any significant difference of clinical response OR in any of seven the studies which indicated the better result of $\mathrm{P} / \mathrm{T}$ versus cefepime monotherapy in cancer patients with FN. Unsurprisingly, based on every individual study, we could not reach the conclusion that $\mathrm{P} / \mathrm{T}$ was superior to cefepime treatment. In terms of combined clinical response, our analysis favored P/T based treatment over cefepime based treatment with the average OR 1.27 and $\mathrm{p}$-value = 0.07 .

As we noticed the differences about the age and treatment duration among patients in the seven studies, we take a further step to make subgroup meta-analysis based on the age and treatment time. We do find some interesting things that the response rate difference between $\mathrm{P} / \mathrm{T}$ and cefepime treatment could be related to the age and time. The young group (age $<=19$ ) showed no significant differences (Fig. 3 : odds ratio $=1.10,95 \%$ confidence interval $=$ 0.73 to $1.65, \mathrm{p}=0.65$ ). While the old group (age $>$ 19) showed a more obvious difference response rate compared with the young (Fig. 4: odds ratio $=1.44$, $95 \%$ confidence interval $=1.00$ to $2.09, \mathrm{p}=0.05$ ). The short-term group (time $<=3 \mathrm{ds}$ ) showed $\mathrm{P} / \mathrm{T}$ treatment was better than cefepime with statistical difference (Fig. 5: odds ratio $=1.40,95 \%$ confidence interval $=1.00$ to $1.95, \mathrm{p}=0.05$ ). While in long-term group (time $>5 \mathrm{ds}$ ), there was no significant difference between $\mathrm{P} / \mathrm{T}$ and cefepime therapy (Figure 6: odds ratio $=1.06,95 \%$ confidence interval $=0.69$ to $1.64, p=0.79$ ). These findings have a valuable impact on the care of 
cancer patients with $\mathrm{FN}$ and future iterations of patient management guideline.

However, this meta-analysis has several limitations and should be viewed in the context of limitations. Firstly, the relative small number of related studies affects the OR and $\mathrm{p}$-value to make a more confirmative and well-founded conclusion. The second limitation is that the sample size from different studies is not evenly distributed and relatively small. Hence, the quality of the analysis is not optimal. The drug administration is similar among the seven included studies. But the baseline characteristics of the participants did not match very well, such as the age of the patients, three studies only included the young participants $<=19$ years old and three studies only included the older participants $>19$ years old. Additionally, some of the included studies are lack of sufficient details about patients, such as participant age, sex distribution and cancer types, to facilitate the interpretation of the results.

Above all, our results from the metaanalysis showed that $\mathrm{P} / \mathrm{T}$ monotherapy is superior to cefepime treatment, with a p-value $=0.07$. Moreover, P/T treatment tends to be more efficient than cefepime treatment in the old patients than the young patients. Short-term treatment of $\mathrm{P} / \mathrm{T}$ is significantly more efficient than cefepie treatment. However, as discussed before, the evidence is limited in many respects. The sample size, especially for the specific subgroup study, was relatively small which may reduce the power of our conclusions. Most importantly, this review highlights that future large-volume, well-designed clinical trials are required to determine the difference between $\mathrm{P} / \mathrm{T}$ and cefepime monotherapy in cancer patients with FN. We offer a new sight to view the effect of cefepime treatment success in cancer patients but not based on mortality.

RESUMO: A Neutropenia Febril (NF) apresenta-se como uma grande ameaça aos pacientes oncológicos após a quimioterapia. $\mathrm{O}$ tratamento antibiótico de amplo espectro é uma prática bem estabelecida para a neutropenia febril. Piperacilina/tazobactam (P/T) é o antibiótico frequentemente na maioria dos casos de NF, enquanto que o uso de cefepima permanece pouco claro em relação ao seu potencial risco. No entanto, pouca análise sistemática foi feita sobre a comparação entre esses dois fármacos. Assim, nós realizamos esta meta-análise para comparar estas duas monoterapias para a neutropenia febril. Através da pesquisa na Pubmed, Google Scholar, nas bases de dados da Medline, EMBASE, OvidSP, ScienceDirect, Web of science e nas bases de dados do China Journal Net (CJN), nós usamos as palavras-chave "(Piperacillin/Tazobactam AND cefepime) AND (febrile neutropenia) AND (cancer or tumor)". Apenas estudos com ensaios clínicos randomizados foram incluídos na meta-análise. Nós selecionamos um número total de sete ensaios clínicos. Esta meta-análise suportou que o tratamento com P/T foi superior ao tratamento com cefepima baseado na média da comparação OU (average OR comparision, em inglês), sem significância estatística (OR $=1.27,95 \%$ confidence interval $=0.98$ to $1.64, \mathrm{p}=0.07$ ). Posteriormente, nós dividimos os sete estudos em dois subgrupos baseados na idade e no tempo de tratamento. O grupo jovem (idade $<=19)$ não mostrou uma diferença significativa $(\mathrm{OR}=1.10, \mathrm{p}=0.65)$. Enquanto que o grupo mais velho (idade $>19$ ) mostrou que o tratamento com P/T foi melhor do que o com cefepima com diferença estatística $(\mathrm{OR}=1.44, \mathrm{p}=0.05)$. O grupo de curto prazo (tempo $<=3 \mathrm{ds} *$ ) mostrou que o tratamento com $\mathrm{P} / \mathrm{T}$ foi melhor do que o com cefepima com diferença estatística $(\mathrm{OR}=1.40, \mathrm{p}=0.05)$. Enquanto isso, no grupo de longo termo (tempo > $5 \mathrm{ds}$ ) não houve diferença significativa entre as terapias com P/T e Cefepima $(\mathrm{OR}=1.06, \mathrm{p}=0.79) . \mathrm{A}$ assimetria nos gráficos de funil (funnel plots, em inglês) não indicaram viés de publicação (CHI $2=1.47$, I2=0\%, and pvalue $=0.96$ ) nesta meta-análise. Seria um bom ensaio clínico utilizar o tratamento P/T para curar NF em pacientes oncológicos comparados com o tratamento com cefepima, especialmente em pacientes adultos ou pacientes submetidos a um tratamento de curto prazo. Esta meta-análise é importante na prática durante o tratamento com antibióticos na administração de NF.

PALAVRAS-CHAVE: Meta-análise. Piperacilina/Tazobactam. Cefepima. Neutropenia Febril. Câncer

\section{REFERENCE}

B HME, A.; SHAH, P. M.; STILLE, W.; HOELZER, D. Piperacillin/tazobactam versus cefepime as initial empirical antimicrobial therapy in febrile neutropenic patients: a prospective randomized pilot study. European journal of medical research, v. 3, n. 7, p. 324-330, 1998. 
BOW, E. J.; ROTSTEIN, C.; NOSKIN, G. A.; LAVERDIERE, M.; SCHWARER, A. P.; SEGAL, B. H.; SEYMOUR, J. F.; SZER, J.; SANCHE, S. A randomized, open-label, multicenter comparative study of the efficacy and safety of piperacillin-tazobactam and cefepime for the empirical treatment of febrile neutropenic episodes in patients with hematologic malignancies. Clin Infect Dis, v. 43, n. 4, p. 447-59, Aug 152006. http://dx.doi.org/10.1086/505393

BRISMAR, B.; MALMBORG, A. S.; TUNEVALL, G.; WRETLIND, B.; BERGMAN, L.; MENTZING, L. O.; NYSTROM, P. O.; KIHLSTROM, E.; BACKSTRAND, B.; SKAU, T.; ET AL. Piperacillin-tazobactam versus imipenem-cilastatin for treatment of intra-abdominal infections. Antimicrob Agents Chemother, v. 36, n. 12, p. 2766-73, Dec 1992. http://dx.doi.org/10.1128/AAC.36.12.2766

CORAPCIOGLU, F.; SARPER, N.; ZENGIN, E. Monotherapy with piperacillin/tazobactam versus cefepime as empirical therapy for febrile neutropenia in pediatric cancer patients: a randomized comparison. Pediatr Hematol Oncol, v. 23, n. 3, p. 177-86, Apr-May 2006. http://dx.doi.org/10.1080/08880010500506370

DEL FAVERO, A.; MENICHETTI, F.; MARTINO, P.; BUCANEVE, G.; MICOZZI, A.; GENTILE, G.; FURNO, P.; RUSSO, D.; D'ANTONIO, D.; RICCI, P.; MARTINO, B.; MANDELLI, F. A multicenter, doubleblind, placebo-controlled trial comparing piperacillin-tazobactam with and without amikacin as empiric therapy for febrile neutropenia. Clin Infect Dis, v. 33, n. 8, p. 1295-301, Oct 15 2001. http://dx.doi.org/10.1086/322646

FANGLI, H.; YANGJIONG, W.; SONG, G.; YING, L.; YIQUN, Y. A randomized study of the efficacy and safety of Piperacillin / tazobactam treatment in multiple myeloma patients with infection Chinese Journal Of Nosocomiology, v. 21, n. 3, p. 557-559, 2011.

FREIFELD, A. G.; BOW, E. J.; SEPKOWITZ, K. A.; BOECKH, M. J.; ITO, J. I.; MULLEN, C. A.; RAAD, II; ROLSTON, K. V.; YOUNG, J. A.; WINGARD, J. R.; INFECTIOUS DISEASES SOCIETY OF, A. Clinical practice guideline for the use of antimicrobial agents in neutropenic patients with cancer: 2010 update by the infectious diseases society of america. Clin Infect Dis, v. 52, n. 4, p. e56-93, Feb 152011.

http://dx.doi.org/10.1093/cid/ciq147

http://dx.doi.org/10.1093/cid/cir073

JACOBSON, K.; ROLSTON, K.; ELTING, L.; LEBLANC, B.; WHIMBEY, E.; HO, D. H. Susceptibility surveillance among gram-negative bacilli at a cancer center. Chemotherapy, v. 45, n. 5, p. 325-34, Sep-Oct 1999. http://dx.doi.org/10.1159/000007223

JAMES, N. D.; HUSSAIN, S. A.; HALL, E.; JENKINS, P.; TREMLETT, J.; RAWLINGS, C.; CRUNDWELL, M.; SIZER, B.; SREENIVASAN, T.; HENDRON, C.; LEWIS, R.; WATERS, R.; HUDDART, R. A.

Radiotherapy with or without Chemotherapy in Muscle-Invasive Bladder Cancer. New England Journal of Medicine, v. 366, n. 16, p. 1477-1488, 2012. http://dx.doi.org/10.1056/NEJMoa1106106

JANDULA, B. M.; MARTINO, R.; GURGI, M.; MANTEIGA, R.; SIERRA, J. Treatment of febrile neutropenia with cefepime monotherapy. Chemotherapy, v. 47, n. 3, p. 226-31, May-Jun 2001. http://dx.doi.org/10.1159/000063226

KUDERER, N. M.; DALE, D. C.; CRAWFORD, J.; COSLER, L. E.; LYMAN, G. H. Mortality, morbidity, and cost associated with febrile neutropenia in adult cancer patients. Cancer, v. 106, n. 10, p. 2258-2266, 2006. http://dx.doi.org/10.1002/cncr.21847

LEHRNBECHER, T.; PHILLIPS, R.; ALEXANDER, S.; ALVARO, F.; CARLESSE, F.; FISHER, B.; HAKIM, H.; SANTOLAYA, M.; CASTAGNOLA, E.; DAVIS, B. L.; DUPUIS, L. L.; GIBSON, F.; GROLL, A. H.; GAUR, A.; GUPTA, A.; KEBUDI, R.; PETRILLI, S.; STEINBACH, W. J.; VILLARROEL, M.; ZAOUTIS, T.; SUNG, L. Guideline for the management of fever and neutropenia in children with cancer and/or undergoing hematopoietic stem-cell transplantation. J Clin Oncol, v. 30, n. 35, p. 4427-38, Dec 102012. http://dx.doi.org/10.1200/JCO.2012.42.7161 
LEIBOVICI, L.; YAHAV, D.; PAUL, M. Meta-analysis of a possible signal of increased mortality associated with cefepime use. Clin Infect Dis, v. 51, n. 11, p. 1350-1; author reply 1351-2, Dec 12010.

http://dx.doi.org/10.1086/657247

LYMAN, G. H.; ABELLA, E.; PETTENGELL, R. Risk factors for febrile neutropenia among patients with cancer receiving chemotherapy: A systematic review. Critical Reviews in Oncology/Hematology, v. 90, n. 3, p. 190-199, 6// 2014.

MONTALAR, J.; SEGURA, A.; BOSCH, C.; GALAN, A.; JUAN, O.; MOLINS, C.; GINER, V.; APARICIO, J. Cefepime monotherapy as an empirical initial treatment of patients with febrile neutropenia. Med Oncol, v. 19, n. 3, p. 161-6, 2002. http://dx.doi.org/10.1385/MO:19:3:161

MORGAN, J. E.; STEWART, L.; PHILLIPS, R. S. Protocol for a systematic review of reductions in therapy for children with low-risk febrile neutropenia. Syst Rev, v. 3, p. 119, 2014. http://dx.doi.org/10.1186/2046-4053-3119

PAUL, M.; YAHAV, D.; FRASER, A.; LEIBOVICI, L. Empirical antibiotic monotherapy for febrile neutropenia: systematic review and meta-analysis of randomized controlled trials. J Antimicrob Chemother, v. 57, n. 2, p. 176-89, Feb 2006. http://dx.doi.org/10.1093/jac/dki448

ROBINSON, P. D.; LEHRNBECHER, T.; PHILLIPS, R.; DUPUIS, L. L.; SUNG, L. Strategies for Empiric Management of Pediatric Fever and Neutropenia in Patients With Cancer and Hematopoietic Stem-Cell Transplantation Recipients: A Systematic Review of Randomized Trials. J Clin Oncol, v. 34, n. 17, p. 2054-60, Jun 10 2016. http://dx.doi.org/10.1200/JCO.2015.65.8591

SANO, H.; KOBAYASHI, R.; SUZUKI, D.; KISHIMOTO, K.; YASUDA, K.; KOBAYASHI, K. Comparison between piperacillin/tazobactam and cefepime monotherapies as an empirical therapy for febrile neutropenia in children with hematological and malignant disorders: A prospective, randomized study. Pediatric Blood \& Cancer, v. 62, n. 2, p. 356-358, 2015.

SANZ, M. A.; LOPEZ, J.; LAHUERTA, J. J.; ROVIRA, M.; BATLLE, M.; PEREZ, C.; VAZQUEZ, L.; JULIA, A.; PALAU, J.; GUTIERREZ, M.; CAPOTE, F. J.; RAMOS, F.; BENLLOCH, L.; LARREA, L.; JARQUE, I. Cefepime plus amikacin versus piperacillin-tazobactam plus amikacin for initial antibiotic therapy in haematology patients with febrile neutropenia: results of an open, randomized, multicentre trial. $\mathbf{J}$

Antimicrob Chemother, v. 50, n. 1, p. 79-88, Jul 2002. http://dx.doi.org/10.1093/jac/dkf087

SERAP, K.; SEMA, V.; YILDIZ, Y.; MERVE, E.; ELA, E.; REJIN, K. Comparison of piperacillin tazobactam and cefoperazone sulbactam monotherapy in treatment of febrile neutropenia. Pediatric Blood \& Cancer, 2012.

SIPAHI, O. R.; ARDA, B.; ZEKA, N. A.; PULLUKCU, H.; TASBAKAN, M.; YAMAZHAN, T.; CALIK, O. S.; SIPAHI, H.; ULUSOY, S. Piperacillin/tazobactam vs. cefoperazone/sulbactam in adult low risk febrile neutropenia cases. International journal of clinical practice, v. 68, n. 2, p. 230-235, 2014. http://dx.doi.org/10.1111/ijcp.12279

TAMME, K.; OSELIN, K.; KIPPER, K.; TASA, T.; METSVAHT, T.; KARJAGIN, J.; HERODES, K.; KERN, H.; STARKOPF, J. Pharmacokinetics and pharmacodynamics of piperacillin/tazobactam during high volume haemodiafiltration in patients with septic shock. Acta Anaesthesiologica Scandinavica, v. 60, n. 2, p. 230-240, 2016. http://dx.doi.org/10.1111/aas.12629

TEUFFEL, O.; ETHIER, M. C.; ALIBHAI, S. M.; BEYENE, J.; SUNG, L. Outpatient management of cancer patients with febrile neutropenia: a systematic review and meta-analysis. Ann Oncol, v. 22, n. 11, p. 2358-65, Nov 2011. http://dx.doi.org/10.1093/annonc/mdq745 
UYGUN, V.; KARASU, G. T.; OGUNC, D.; YESILIPEK, A.; HAZAR, V. Piperacillin/tazobactam versus cefepime for the empirical treatment of pediatric cancer patients with neutropenia and fever: a randomized and open-label study. Pediatr Blood Cancer, v. 53, n. 4, p. 610-4, Oct 2009. http://dx.doi.org/10.1002/pbc.22100

VIDAL, L.; BEN DOR, I.; PAUL, M.; ELIAKIM-RAZ, N.; POKROY, E.; SOARES-WEISER, K.; LEIBOVICI, L. Oral versus intravenous antibiotic treatment for febrile neutropenia in cancer patients.

Cochrane Database Syst Rev, v. 10, p. CD003992, 2013. http://dx.doi.org/10.1002/14651858.cd003992.pub3

WI, Y. M.; CHUNG, D. R.; SONG, J. H.; PECK, K. R. Comparative Study of Piperacillin/Tazobactam and Cefepime in Cancer Patients with Febrile Neutropenia. International Journal of Infectious Diseases, v. 12, 2008.

WINGARD, J. R.; MARR, K. A.; THORNER, A. R. Treatment of neutropenic fever syndromes in adults with hematologic malignancies and hematopoietic cell transplant recipients (high-risk patients). Uptodate. com, 2013. 